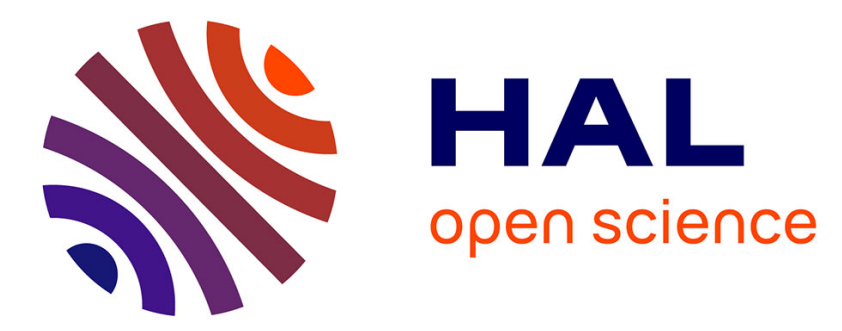

\title{
Human mortality effects of future concentrations of tropospheric ozone
}

\author{
J. Jason West, Sophie Laval-Szopa, Didier Hauglustaine
}

\section{To cite this version:}

J. Jason West, Sophie Laval-Szopa, Didier Hauglustaine. Human mortality effects of future concentrations of tropospheric ozone. Comptes Rendus Géoscience, 2007, 339 (11-12), pp.775-783. 10.1016/J.CRTE.2007.08.005 . hal-03048483

\section{HAL Id: hal-03048483 \\ https://hal.science/hal-03048483}

Submitted on 10 Dec 2020

HAL is a multi-disciplinary open access archive for the deposit and dissemination of scientific research documents, whether they are published or not. The documents may come from teaching and research institutions in France or abroad, or from public or private research centers.
L'archive ouverte pluridisciplinaire $\mathbf{H A L}$, est destinée au dépôt et à la diffusion de documents scientifiques de niveau recherche, publiés ou non, émanant des établissements d'enseignement et de recherche français ou étrangers, des laboratoires publics ou privés. 


\title{
External Geophysics, Climate and Environment (Climatology) Human mortality effects of future concentrations of tropospheric ozone
}

\author{
J. Jason West ${ }^{\mathrm{a}, *}$, Sophie Szopa ${ }^{\mathrm{b}}$, Didier A. Hauglustaine ${ }^{\mathrm{b}}$ \\ ${ }^{a}$ Department of Environmental Sciences and Engineering, University of North Carolina at Chapel Hill, 164 Rosenau Hall, CB \#7431, \\ Chapel Hill, NC 27599, USA \\ ${ }^{\mathrm{b}}$ Laboratoire des sciences du climat et de l'environnement (LSCE/IPSL), laboratoire CEA/CNRS/université de Versailles-Saint-Quentin, \\ L'Orme des Merisiers, 91191 Gif-sur-Yvette, France
}

Received 27 May 2007; accepted after revision 2 August 2007

Available online 14 September 2007

Written on invitation of the Editorial Board

\begin{abstract}
Here we explore the effects of projected future changes in global ozone concentrations on premature human mortality, under three scenarios for 2030. We use daily surface ozone concentrations from a global atmospheric transport and chemistry model, and ozone-mortality relationships from daily time-series studies. The population-weighted annual average 8-h daily maximum ozone is projected to increase, relative to the present, in each of ten world regions under the SRES A2 scenario and the current legislation (CLE) scenario, with the largest growth in tropical regions, while decreases are projected in each region in the maximum feasible reduction (MFR) scenario. Emission reductions in the CLE scenario, relative to A2, are estimated to reduce about 190,000 premature human mortalities globally in 2030, with the most avoided mortalities in Africa. The MFR scenario will avoid about 460,000 premature mortalities relative to A2 in 2030, and 270,000 relative to CLE, with the greatest reductions in South Asia.
\end{abstract} To cite this article: J.J. West et al., C. R. Geoscience 339 (2007).

(C) 2007 Académie des sciences. Published by Elsevier Masson SAS. All rights reserved.

\section{Résumé}

Effets des futures concentrations d'ozone troposphérique sur la mortalité humaine. Ce travail a pour but de quantifier les effets de trois projections différentes de changements futurs de concentrations d'ozone global sur la mortalité humaine prématurée, à l'horizon 2030. Pour cela, nous utilisons les concentrations journalières d'ozone de surface issues d'un modèle global de chimietransport atmosphérique et les relations ozone-mortalité tirées d'analyses de séries temporelles journalières. Par rapport aux teneurs actuelles, une augmentation des maximums journaliers d'ozone (calculés à partir des moyennes sur $8 \mathrm{~h}$ pondérées par la population) est prévue en 2030 pour les 10 régions du monde étudiées dans le cas des scénarios SRES-A2 et mises en oeuvre des législations actuelles (CLE). L'augmentation la plus grande est prévue dans les régions tropicales. Au contraire, lorsque le scénario « maximum de réductions techniquement possibles » (MFR) est envisagé, des diminutions des maximums journaliers d'ozone sont prévues pour chacune des régions. Selon nos estimations, les réductions d'émissions dans le scénario CLE induisent, en regard du scénario A2, une réduction d'environ 190000 morts prématurées au niveau mondial en 2030, avec un maximum de morts évitées en Afrique. La mise en œuvre du scénario MFR permettrait d'éviter environ 460000 morts prématurées en 2030, si on le compare au scénario

\footnotetext{
* Corresponding author.

E-mail address: jjwest@email.unc.edu (J.J. West).
} 
A2 et 270000 si on le compare au scénario CLE, avec la réduction la plus grande en Asie du Sud. Pour citer cet article : J.J. West et al., C. R. Geoscience 339 (2007).

(C) 2007 Académie des sciences. Published by Elsevier Masson SAS. All rights reserved.

Keywords: Ozone; Air pollution; Human mortality; Atmospheric modeling; Health effects; Future scenarios; Tropospheric chemistry

Mots clés : Ozone ; Pollution de l'air ; Mortalité humaine ; Modélisation atmosphérique ; Effets sur la santé ; Scénarios futurs ; Chimie troposphérique

\section{Introduction}

Projecting the concentrations of trace species in the troposphere over the next several decades is important for projecting climate change, as well as for understanding the effects of air pollutants on human health, agricultural productivity, and natural ecosystems. Projecting future emissions of primary particulate matter (PM), and of the precursors of ozone and secondary PM, is likewise important when considering the long-range transport of air pollutants and, for example, the effect of growing emissions in emerging countries on air quality in industrialized nations.

In this study, we address the effects of future ozone concentrations on premature human mortality, in several scenarios for 2030. Ozone is an atmospheric oxidant that has been associated with adverse health effects including hospital admissions and chronic respiratory conditions. In addition, a substantial epidemiological literature documents an association between ozone and premature human mortality through daily time-series studies $[1-5,9,12-15,19,22,26]$.

PM is another major air pollutant that has also been associated with premature mortality, in both daily time series studies and long-term cohort studies [20]. Because PM has been demonstrated to have long-term chronic effects on mortality, while chronic effects have not been demonstrated for ozone, future changes in PM concentrations are likely the most important component of changes in mortalities due to air pollution in future scenarios. While this study focuses on future mortality associated with changes in ozone, an assessment of the total mortality effects of air pollutants would also need to account for changes in PM mortality.

Here we evaluate human mortality globally due to changes in surface ozone concentrations under three scenarios for 2030. We use the results of global atmospheric modeling studies performed by Szopa et al. [24] and Szopa and Hauglustaine [25] to give surface ozone changes. The next section describes these atmospheric modeling simulations and our methods of estimating global human mortality effects associated with these changes in ozone. We then present our estimates of human mortality globally and in ten world regions.

\section{Methods}

We use results from a global atmospheric modeling exercise performed using a coupled general circulation model with interactive chemistry, the LMDz-INCA chemistry-climate model [8,10,11]. Modeled ozone concentrations for present conditions using this model are shown to agree reasonably well with surface ozone measurements $[8,10]$.

The global simulations used in this study are described fully by Szopa et al. [24] and Szopa and Hauglustaine [25], and these simulations were shown previously to be within the range of several other models in the Photocomp experiment [7,23]. While Szopa et al. [24] and Szopa and Hauglustaine [25] also present results for a regional model imbedded over Europe, and consider climate change scenarios in the future, we consider here only the results of the global model using present-day meteorology (for 2000 from the ECMWF ERA40 reanalysis).

Four scenarios are considered in this study: a simulation for 2000, and projected 2030 emissions under the SRES A2 scenario, the CLE (current legislation) scenario, and the MFR (maximum feasible reduction) scenario. The SRES A2 scenario [17] is a high-growth scenario with rapid increases in emissions of air pollutants. The CLE scenario takes into consideration recently-enacted legislation to improve air quality in nations around the world, and the MFR scenario assumes that currently available emission control technologies are aggressively employed globally [6]. LMDz-INCA is run with a horizontal resolution of $3.75^{\circ}$ in longitude and $2.5^{\circ}$ in latitude, and mortality effects are calculated on this grid also. Using hourly surface ozone concentrations, we calculate the daily maximum 8-h average ozone concentration on each day and at each grid cell, and use these 8-h maxima to drive the ozone mortality estimates. 
We estimate effects of changes in ozone on premature human mortality for several scenarios, following the methods used by West et al. [27]. We use the results of an epidemiological daily time-series study that relates ozone with daily mortalities, using a distributed lag method and a large database for 95 cities in the United States [2]. The equation for a change in human mortalities ( $\Delta$ Mort) due to a change in ozone concentration $\left(\Delta \mathrm{O}_{3}\right)$ used in the epidemiological study and in this study is:

$\Delta M o r t=-y_{0}\left(e^{-\beta \Delta \mathrm{O}_{3}}-1\right) P o p$

where $y_{0}$ is the baseline mortality rate for a given population, $\beta$ is the mortality coefficient (fraction excess mortalities per ppbv of ozone), and Pop is the total population. We use the total non-accident baseline mortality rates $\left(y_{0}\right)$ for the whole population in each of 14 world regions, obtained from the World Health Organization [28], and we assume that these baseline mortality rates are constant to 2030 .

The $\beta$ that we have selected from Bell et al. [2] is consistent with, but generally smaller than, metaanalyses of ozone mortality that have been published since $2001[1,3,12,14,15,22,26]$. We selected this $\beta$ because it is not subject to publication bias (the possible tendency to selectively publish positive results), which may bias meta-analyses high. While this value of $\beta$ was estimated in the US, we assume that this ozonemortality relationship is valid globally, as similar results have been demonstrated in Europe [9] and in some locations in the less industrialized world $[5,13,19]$. We use a value of $\beta$ that was derived for the daily maximum 8-h ozone. While some studies have tried to distinguish the ozone-mortality relationship for different populations, such as by age or by the proximate cause of death, these attempts generally do not find significant differences from the whole population [2]. Consequently, we use a value of $\beta$ derived for the whole population, and apply it to the whole population. Since long-term effects of ozone on mortality have not been demonstrated [20], we do not consider possible chronic effects of ozone on mortality, nor the years of life lost due to premature mortality.

The growth in global population and its spatial distribution is modeled in four world regions, according to the SRES A2 scenario [17], totaling 6.17 billion in 2000 and 9.17 billion in 2030. The spatial distribution of population within each region is based on the 2003 population from the LandScan database [18], which provides population data at very fine resolution, and which we then map onto the atmospheric modeling grid.
Equation (1) is applied in each grid cell and on each day, using the change in the daily maximum 8-h ozone concentration on that day, the population of that grid cell, and the value of $y_{0}$ corresponding to the appropriate world region. Since it is applied on each day, $\beta$ is divided by 365.25 days per year. Equation (1) is prescribed for a change in ozone concentration, and epidemiological studies can effectively evaluate $\beta$ over the range of ozone concentrations for which there are observations. While most ozone measurements in these studies are in the range of modest ozone, some studies show evidence that a similar ozone-mortality relationship holds at low concentrations, well below current national standards, and question whether a low-concentration threshold exists $[4,9]$. Estimating the total mortality burden due to ozone would require one to specify a reference ozone concentration or field against which current levels would be compared. Because the ozone-mortality relationship has not been firmly established at low concentration, and because specifying a reference case is beyond the scope of this study, we do not estimate the total mortality burden of ozone. Rather, we estimate ozone mortality due to differences in ozone concentration between the different scenarios considered.

We evaluate ozone mortality assuming a lowconcentration threshold of 25 ppbv, below which changes in ozone are assumed to have no effect on human mortality. Using such a threshold replaces estimating mortality in particular seasons; epidemiological studies in temperate regions have often segregated results by season, but these seasons do not have the same relevance in tropical nations [27]. We choose a threshold at roughly the current background concentration, as the effect of ozone on mortality is uncertain at low concentrations. Since this choice of a threshold is fairly arbitrary, we test the sensitivity of the results to this threshold level.

\section{Results}

Szopa et al. [24] and Szopa and Hauglustaine [25] present global results for the set of scenarios that we consider; here we present population-weighted concentrations, as indicators which are relevant for human health. Table 1 shows the population-weighted annual average 8-h daily maximum surface ozone concentration, globally and in each of ten world regions. Definitions of these ten regions are shown in Fig. 1.

The results in Table 1 indicate a very substantial increase in ozone globally in 2030 under the A2 scenario, relative to the 2000 simulation, with the global population-weighted 8-h ozone increasing by $9.4 \mathrm{ppbv}$. 
Table 1

The population-weighted annual average 8-h daily maximum ozone in the 2000 reference case and in three scenarios for 2030 (ppbv), shown globally and for ten world regions

Tableau 1

Maximum d'ozone moyen sur $8 \mathrm{~h}$ pondéré par la population (ppbv) dans le cas de référence de l'année 2000 et dans les trois scénarios pour 2030 , à l'échelle mondiale et pour les dix régions considérées

\begin{tabular}{|c|c|c|c|c|c|}
\hline & $2000^{\mathrm{a}}$ & $2000^{b}$ & A2 2030 & CLE 2030 & MFR 2030 \\
\hline Africa & 39.3 & 39.4 & 48.5 & 42.0 & 36.9 \\
\hline Middle East & 45.7 & 45.6 & 56.1 & 49.4 & 39.3 \\
\hline South Asia & 45.5 & 45.5 & 60.3 & 54.4 & 39.3 \\
\hline Southeast Asia & 33.5 & 33.5 & 42.1 & 37.7 & 29.5 \\
\hline East Asia & 44.9 & 44.9 & 53.0 & 46.7 & 38.5 \\
\hline Japan \& Australia & 42.4 & 42.4 & 48.3 & 43.5 & 36.6 \\
\hline Former Soviet Union & 41.2 & 41.2 & 47.5 & 43.0 & 36.9 \\
\hline Europe & 40.4 & 40.3 & 45.1 & 42.2 & 37.3 \\
\hline North America & 46.4 & 46.4 & 52.1 & 48.0 & 40.9 \\
\hline Latin America & 35.9 & 35.9 & 44.5 & 36.7 & 31.0 \\
\hline Global & 41.9 & 41.7 & 51.1 & 45.3 & 36.7 \\
\hline
\end{tabular}

\footnotetext{
${ }^{\mathrm{a}}$ Using the 2000 population distribution.
}

${ }^{b}$ Using the 2030 population distribution for comparison with the 2030 scenarios.

The projected increase in ozone in the A2 scenario is greatest over South Asia (nearly $15 \mathrm{ppbv}$ ), with large increases also in the Middle East, Africa, Southeast Asia, Latin America, and East Asia. This substantial growth in ozone in the A2 scenario, particularly over South Asia, has been simulated previously using other models $[7,21]$.

These regional changes in ozone are the result of a combination of changed emissions within each region, and background influences due to increases in emissions in other regions and growth in the global background ozone concentration itself. Fig. 2 shows the regional changes in emissions in the 2030 scenarios, relative to the 2000 base simulation. In the A2 scenario, emissions of $\mathrm{CO}, \mathrm{NO}_{x}$, and NMVOCs increase in all world regions. While the absolute growth in emissions in South Asia is not larger than in other regions, it has the highest growth in population-weighted ozone. The Middle East, Africa, and Southeast Asia also have large

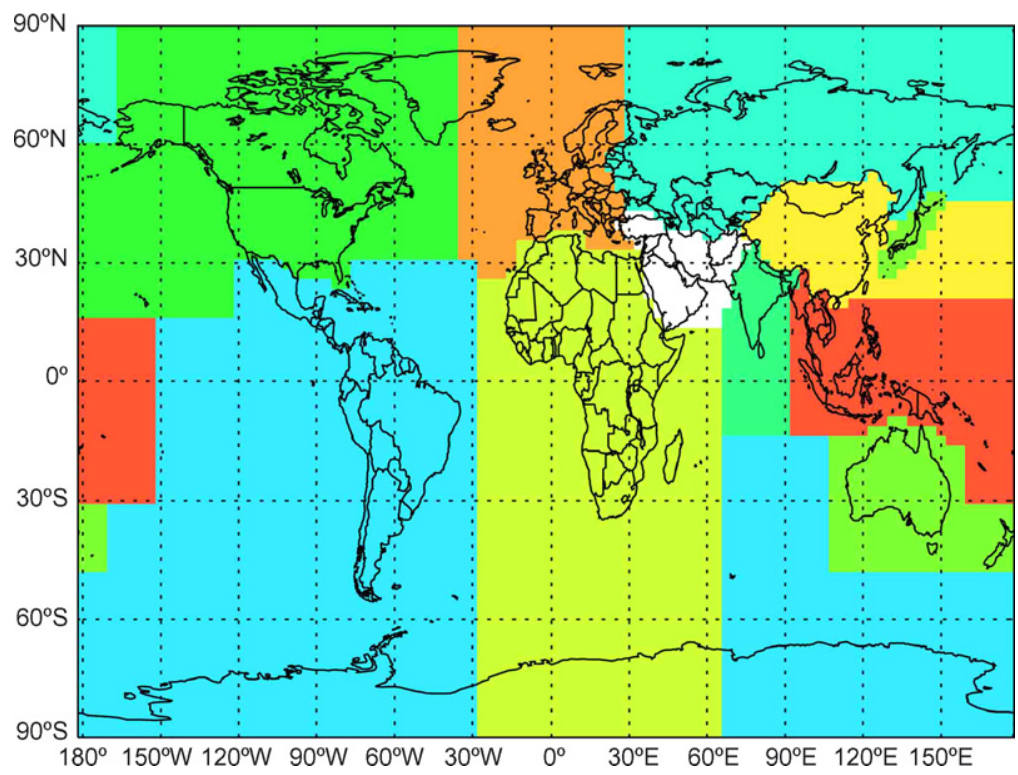

Fig. 1. Definitions for ten world regions used in this study, on the $3.75 \times 2.5^{\circ}$ grid used for LMDz-INCA modeling. Note that Australia, New Zealand, and Japan form one divided region.

Fig. 1. Définitions des dix régions du monde étudiées dans cette étude, basées sur la grille du modèle $\mathrm{LMDz}-\mathrm{INCA}\left(3,75^{\circ}\right.$ long. $\times 2,5^{\circ} 1$ lat. $)$. Note : l'Australie, la Nouvelle-Zélande et le Japon sont inclus dans une même région. 
(a)

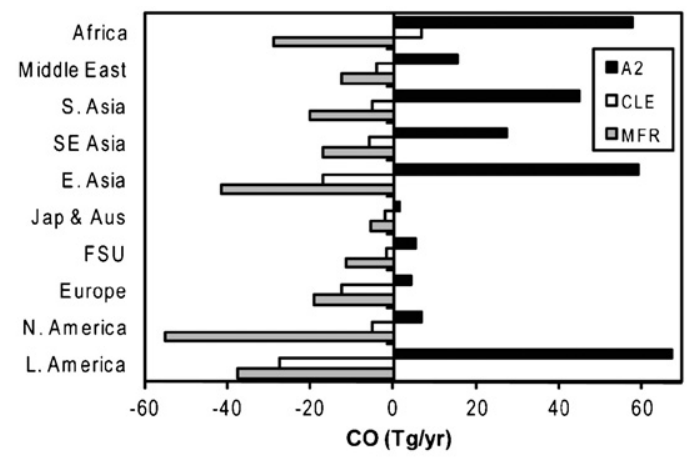

(b)

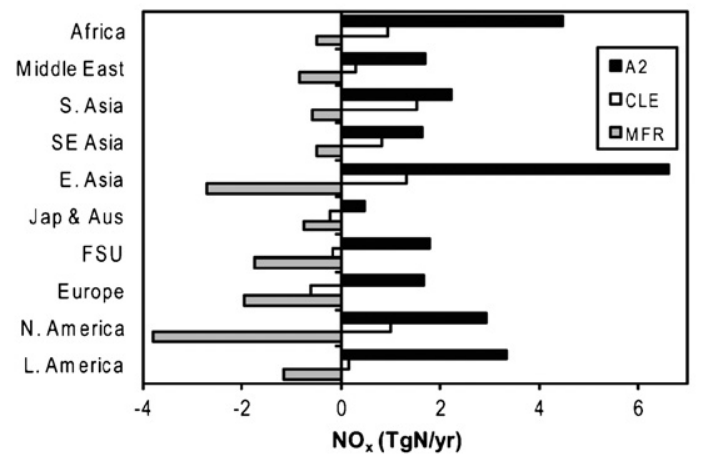

(c)

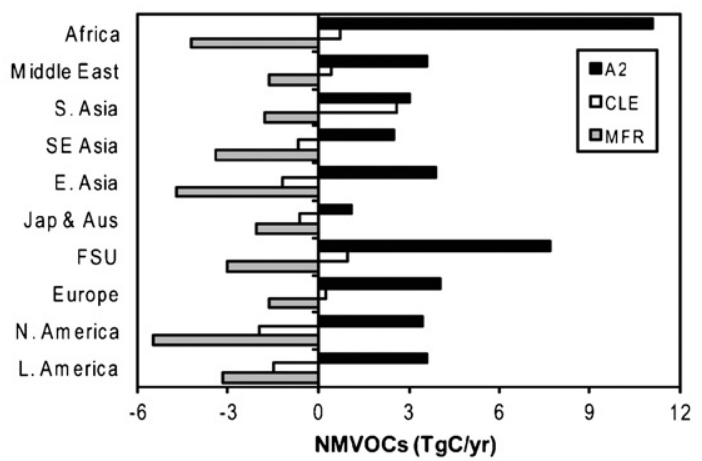

Fig. 2. Changes in surface emissions in three 2030 scenarios relative to the 2000 case, in ten world regions, for (a) $\mathrm{NO}_{x}$, (b) $\mathrm{CO}$, and (c) NMVOCs. Global emissions in 2000 (from all surface sources) were

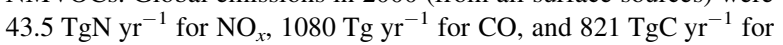
NMVOCs.

Fig. 2. Changement d'émissions dans les trois scénarios 2030 par rapport aux émissions actuelles (2000), pour dix régions du monde, pour (a) les $\mathrm{NO}_{x}$, (b) le $\mathrm{CO}$ et (c) les NMVOCs. Note : Les émissions mondiales en 2000 (pour toutes les sources de surface) étaient de $43,5 \mathrm{TgN} \mathrm{yr}^{-1}$ pour les $\mathrm{NO}_{x}, 1080 \mathrm{Tg} \mathrm{yr}^{-1}$ pour $\mathrm{CO}$, et $821 \mathrm{TgC} \mathrm{yr}^{-1}$ pour les NMVOCs.

increases in ozone, despite the fact that emissions increases are comparable to those in East Asia and North America. This suggests that the production of ozone per unit change in emissions is greater in tropical regions than in temperate regions, which is consistent with other model results [16].
The population-weighted ozone is likewise projected to increase in all world regions in the CLE scenario, again with very large increases in South Asia (9 ppbv). Ozone increases in the CLE scenario despite decreases in $\mathrm{NO}_{x}$ emissions in Europe, the former Soviet Union, Japan, and Australia, due to the increase in global ozone concentrations and long-range transport [25]. Ozone is estimated to decrease in all regions in the MFR scenario, relative to 2000, with the largest decreases in East Asia, the Middle East, and South Asia. The increase in all regions under CLE, and decrease in MFR is consistent with results from several models [7]; our reported ozone changes are greater than Dentener et al. [7] reported, because of our use of population-weighted 8 -h ozone indicators, rather than area-weighted annual averages.

We focus on changes in human mortality in the three 2030 scenarios. Table 2 shows the avoided mortalities in 2030 under the CLE scenario relative to A2, using the low-concentration threshold of $25 \mathrm{ppbv}$. We estimate a total of 191,000 avoided mortalities globally, which is roughly $0.2 \%$ of the projected total number of annual deaths in 2030. The largest numbers of avoided mortalities occur in Africa, South Asia, and East Asia, as these three regions have the highest projected total population. We also show the avoided mortalities per million people, showing that Africa, the former Soviet Union, and South Asia are the highest. Africa has the highest total mortalities and mortalities per million people mainly because it has the highest baseline mortality rate in the world (mainly due to poor access to health care, food, and sanitation), followed by the former Soviet Union (because of an aging population). The avoided mortalities per million people are least in Southeast Asia, Europe, and North America, due to small changes in ozone and/or low baseline mortality rates.

In our estimates of the total avoided premature mortalities, we apply globally the ozone-mortality relationship derived from a study in the US [2]. While few ozone-mortality studies have been conducted in the less industrialized world, the general causes of death differ among world regions. Because of this, we also show the avoided cardiovascular and respiratory $(C \& R)$ mortalities. $C \& R$ causes are the most likely means by which ozone affects mortality, although Bell et al. [2] found that the $\beta$ for $\mathrm{C} \& \mathrm{R}$ mortalities was not significantly different from the $\beta$ for total mortalities. We use the $\beta$ for $\mathrm{C} \& \mathrm{R}$ mortalities [2] and use the baseline mortality rates for only C\&R mortalities. We estimate that 103,000 avoided premature $C \& R$ mortalities result under CLE relative to A2, and Table 2 shows that Africa does not have the highest number of avoided $C \& R$ mortalities nor 
Table 2

Projected 2030 population in each of ten regions and globally, the change in the population-weighted annual average 8-h daily maximum ozone, and annual avoided total mortalities and cardiovascular \& respiratory (C\&R) mortalities, in 2030 for the CLE scenario relative to A2

Tableau 2

Population prévue en 2030 dans chacune des dix régions et au niveau mondial. Différences en 2030 pour le scénario CLE par rapport au scénario A2 du maximum d'ozone moyen sur $8 \mathrm{~h}$, pondéré par la population, du nombre de morts totales et du nombre de morts liées aux problèmes cardiovasculaires et respiratoires (C\&R)

\begin{tabular}{|c|c|c|c|c|c|c|}
\hline & $\begin{array}{l}2030 \text { population } \\
\text { (million) }\end{array}$ & $\begin{array}{l}\text { Change in } \\
\mathrm{O}_{3} \text { (ppbv) }\end{array}$ & $\begin{array}{l}\text { Avoided } \\
\text { mortalities }^{\mathrm{a}}\end{array}$ & $\begin{array}{l}\text { Avoided mortalities } \\
\text { per million people }\end{array}$ & $\begin{array}{l}\text { Avoided C\&R } \\
\text { mortalities }^{\mathrm{a}}\end{array}$ & $\begin{array}{l}\text { Avoided C\&R mortalities } \\
\text { per million people }\end{array}$ \\
\hline Africa & 1590 & -6.5 & 58,400 & 36.7 & 18,900 & 11.9 \\
\hline Middle East & 567 & -6.8 & 10,500 & 18.6 & 6300 & 11.2 \\
\hline South Asia & 1802 & -5.9 & 39,000 & 21.6 & 23,000 & 12.7 \\
\hline Southeast Asia & 825 & -4.4 & 9900 & 12.0 & 6200 & 7.5 \\
\hline East Asia & 1954 & -6.3 & 33,900 & 17.3 & 23,300 & 11.9 \\
\hline Japan \& Australia & 171 & -4.8 & 2400 & 13.7 & 1500 & 8.5 \\
\hline Former Soviet Union & 322 & -4.5 & 7400 & 23.1 & 6700 & 20.7 \\
\hline Europe & 585 & -3.0 & 7100 & 12.1 & 5100 & 8.7 \\
\hline North America & 371 & -4.1 & 4900 & 13.3 & 3100 & 8.4 \\
\hline Latin America & 982 & -7.7 & 17,400 & 17.7 & 9400 & 9.6 \\
\hline Global & 9170 & -5.9 & 191,000 & 20.8 & 103,000 & 11.3 \\
\hline
\end{tabular}

${ }^{a}$ Avoided mortalities are rounded to the nearest 100 mortalities in each region and to the nearest 1000 mortalities globally.

C\&R mortalities per million people. Rather, the former Soviet Union has the most C\&R mortalities per million people, as it has an aging population for whom most deaths are due to $C \& R$ causes. The estimated avoided $\mathrm{C} \& \mathrm{R}$ mortalities can be thought of as a lower bound on the total mortalities, but it likely omits other means by which ozone may affect mortality.

Table 3 shows the avoided mortalities in 2030 for the MFR scenario relative to A2, with an estimated 458,000 avoided mortalities in $2030(\sim 0.5 \%$ of total 2030 mortalities), and 259,000 avoided C\&R mortalities. The MFR scenario causes ozone in South Asia to decrease substantially, by more than 20 ppbv for the population- weighted 8-h ozone. Consequently, South Asia has the largest number of avoided mortalities per million people in this scenario.

As some people consider the CLE scenario the most likely scenario to 2030, we also consider the avoided mortalities in the MFR scenario with respect to the CLE scenario (Table 4). The results show 267,000 avoided premature mortalities globally $(\sim 0.3 \%$ of total projected mortalities), and 155,000 C\&R mortalities, with the largest number of avoided mortalities in South Asia because of the very large reduction in ozone in this region (about $15 \mathrm{ppbv}$ for the population-weighted 8-h ozone). Note that the results in Tables 2 and 4 do not add

Table 3

The change in the population-weighted annual average 8-h daily maximum ozone, and annual avoided total mortalities and cardiovascular \& respiratory mortalities, in 2030 for the MFR scenario relative to A2, shown globally and for ten world regions

Tableau 3

Différences en 2030 pour le scénario MFR par rapport au scénario A2 du maximum d'ozone moyen sur $8 \mathrm{~h}$ pondéré par la population, du nombre de morts totales et du nombre de morts liées aux problèmes cardiovasculaires et respiratoires $(\mathrm{C} \& \mathrm{R})$

\begin{tabular}{|c|c|c|c|c|c|}
\hline & $\begin{array}{l}\text { Change in } \\
\mathrm{O}_{3} \text { (ppbv) }\end{array}$ & $\begin{array}{l}\text { Avoided } \\
\text { mortalities }\end{array}$ & $\begin{array}{l}\text { Avoided mortalities } \\
\text { per million people }\end{array}$ & $\begin{array}{l}\text { Avoided C\&R } \\
\text { mortalities }\end{array}$ & $\begin{array}{l}\text { Avoided C\&R mortalities } \\
\text { per million people }\end{array}$ \\
\hline Africa & -11.6 & 100,500 & 63.2 & 33,400 & 21.0 \\
\hline Middle East & -16.9 & 28,000 & 49.3 & 16,000 & 28.3 \\
\hline South Asia & -21.0 & 142,100 & 78.9 & 83,700 & 46.5 \\
\hline Southeast Asia & -12.6 & 26,300 & 31.8 & 16,300 & 19.7 \\
\hline East Asia & -14.5 & 77,500 & 39.7 & 53,200 & 27.2 \\
\hline Japan \& Australia & -11.6 & 5600 & 32.9 & 3500 & 20.3 \\
\hline Former Soviet Union & -10.7 & 17,800 & 55.2 & 15,900 & 49.4 \\
\hline Europe & -7.9 & 17,700 & 30.3 & 12,600 & 21.6 \\
\hline North America & -11.2 & 13,700 & 37.1 & 8600 & 23.3 \\
\hline Latin America & -13.4 & 28,900 & 29.5 & 15,700 & 16.0 \\
\hline Global & -14.4 & 458,000 & 50.0 & 259,000 & 28.2 \\
\hline
\end{tabular}


Table 4

As Table 3 but for the MFR scenario relative to CLE in 2030

Table 4

Idem Tableau 3, mais pour le scénario MFR par rapport au scénario CLE en 2030

\begin{tabular}{|c|c|c|c|c|c|}
\hline & $\begin{array}{l}\text { Change in } \\
\mathrm{O}_{3} \text { (ppbv) }\end{array}$ & $\begin{array}{l}\text { Avoided } \\
\text { mortalities }\end{array}$ & $\begin{array}{l}\text { Avoided mortalities } \\
\text { per million people }\end{array}$ & $\begin{array}{l}\text { Avoided C\&R } \\
\text { mortalities }\end{array}$ & $\begin{array}{l}\text { Avoided C\&R mortalities } \\
\text { per million people }\end{array}$ \\
\hline Africa & -5.1 & 42,100 & 26.4 & 14,400 & 9.1 \\
\hline Middle East & -10.1 & 17,400 & 30.6 & 9700 & 17.1 \\
\hline South Asia & -15.1 & 102,800 & 57.0 & 60,500 & 33.6 \\
\hline Southeast Asia & -8.2 & 16,400 & 19.8 & 10,000 & 12.2 \\
\hline East Asia & -8.2 & 43,400 & 22.2 & 29,800 & 15.2 \\
\hline Japan \& Australia & -6.9 & 3300 & 19.1 & 2000 & 11.8 \\
\hline Former Soviet Union & -6.2 & 10,300 & 32.0 & 9200 & 28.6 \\
\hline Europe & -4.9 & 10,600 & 18.2 & 7500 & 12.9 \\
\hline North America & -8.5 & 8800 & 23.7 & 5500 & 14.9 \\
\hline Latin America & -7.1 & 11,500 & 11.7 & 6200 & 6.4 \\
\hline Global & -8.5 & 267,000 & 29.1 & 155,000 & 16.9 \\
\hline
\end{tabular}

simply to give Table 3, due to the nonlinearity in the ozone-mortality function and the presence of the lowconcentration threshold.

Because both ozone and population change between 2000 and 2030, it is not possible to estimate directly the increased mortalities between the 2000 base simulation and the 2030 scenarios. We approximate this change by estimating the change in mortality in 2000 with respect to a hypothetical case where ozone is uniformly equal to the 25-ppbv threshold, which one might argue would represent the total mortality burden of ozone. We subtract this estimate of mortality from similar results when the 2030 A2 scenario is estimated relative to the uniform $25 \mathrm{ppbv}$ threshold. The results give 500,000 total excess mortalities annually under A2 (with respect to 2000), and 271,000 C\&R mortalities, where these differences are due to both increasing ozone globally and increasing population.

The mortality estimates shown previously are estimated with an ozone-mortality threshold of $25 \mathrm{ppbv}$. Fig. 3 shows the total avoided mortalities as a function of the threshold assumed, for three cases, corresponding to Tables 2-4. The results show that for thresholds below $25 \mathrm{ppbv}$, there is very little effect on the total estimated mortalities, with results at 25 ppbv only $1-2 \%$ lower than with no threshold. At higher thresholds, the importance of the threshold is substantial. While the threshold has a minor effect at 25 ppbv, a substantial number of grid celldays fall below the threshold. At a threshold of $25 \mathrm{ppbv}$, $12 \%$ of the populated grid cell-days (that is, for grid cells where at least one person lives) are below the threshold in the A2 case, and 24\% in MFR, while mortality only decreases by $2 \%$ because of the threshold. At a $50 \mathrm{ppbv}$ threshold, $86 \%$ are below the threshold for A2, and $95 \%$ for MFR, while mortality decreases by
53\%. This difference arises because areas with high ozone also tend to be highly populated.

In addition to uncertainty in the low-concentration threshold, we consider the sensitivity of the estimated global avoided premature mortalities to other uncertain parameters in Fig. 4. The value of $\beta$ has a large effect on the estimated avoided mortalities, and if we use the range of $\beta$ from three recent meta-analyses, higher ranges of avoided mortalities result. The response of ozone concentration to the change in emissions is also associated with a large uncertainty and causes a broad range of results. We do not consider uncertainty in the emissions scenarios themselves, since these are considered as alternative scenarios intended to illustrate a range of plausible futures. Because the ozone response and the low-concentration threshold are not independent, an assessment of the total uncertainty would

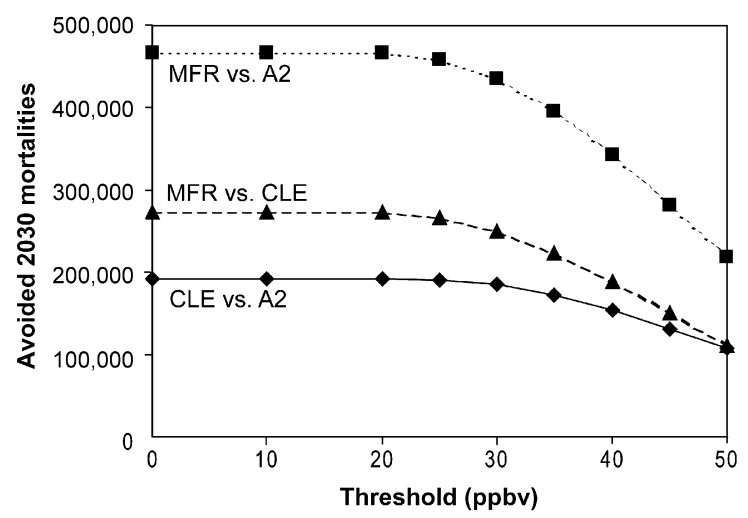

Fig. 3. Estimated avoided 2030 mortalities globally as a function of the low-concentration ozone-mortality threshold.

Fig. 3. Estimation des morts évitées en 2030 au niveau mondial en fonction du seuil considéré pour les faibles concentrations dans la relation ozone-mortalité. 


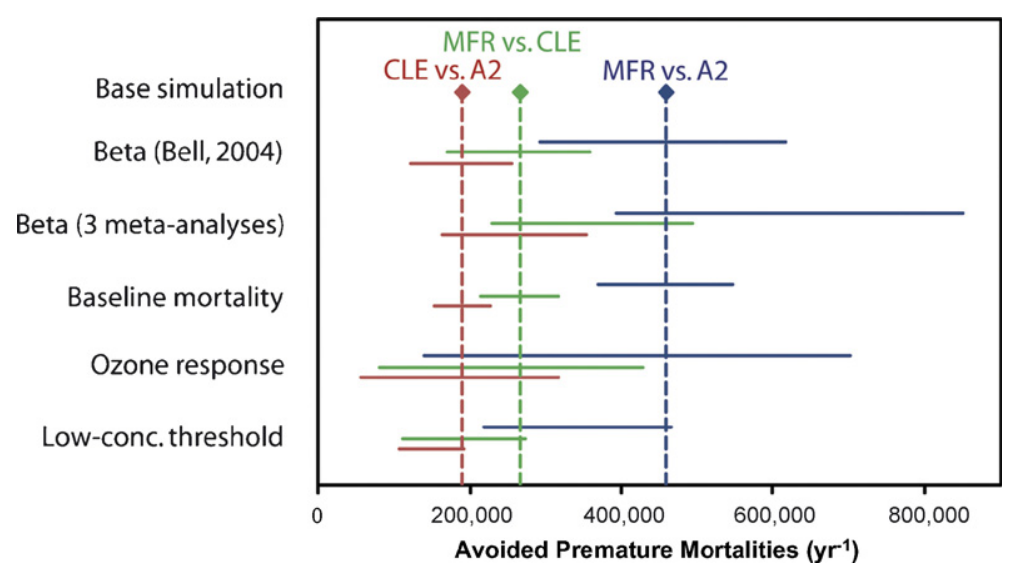

Fig. 4. Parametric uncertainty analysis of the global avoided premature mortalities. The three uncertainty ranges for each parameter correspond to the three base estimates above. The uncertainty in $\beta$ considers the $95 \%$ confidence interval used by Bell et al. [2], and a range spanning the 95\% confidence intervals of three meta-analyses $[3,12,15]$. Uncertainty for the 2030 baseline mortality is taken to be $\pm 10 \%$ in industrialized nations and $\pm 20 \%$ in the rest of the world. Uncertainty in the ozone response is $\pm 70 \%$ based on the ranges of many models run under these scenarios, reported by Dentener et al. [7] (we select a range wider than the standard deviation reported for 2030 A2 relative to the present). This range for the change in ozone is applied as scaling factors to the change in 8-h ozone in each grid cell on each day. Uncertainty in the low-concentration threshold corresponds to thresholds of 0 and 50 ppbv in Fig. 3.

Fig. 4. Incertitudes liées aux paramètres utilisés dans l'estimation de la mortalité prématurée évitée à l'échelle globale. Ces intervalles d'incertitude sont donnés pour les trois scénarios. L'incertitude sur $\beta$ considère l'intervalle de confiance de $95 \%$ utilisé par Bell et al. [2] et un intervalle concordant avec l'intervalle de confiance de $95 \%$ de trois méta-analyses [3,12,15]. L'incertitude sur la mortalité de référence en 2030 est fixée à $\pm 10 \%$ dans les pays industrialisés et $\pm 20 \%$ dans le reste du monde. L'incertitude dans la réponse de l'ozone aux changements futurs d'émissions est de $\pm 70 \%$ sur la base de l'intervalle entre les résultats de différents modèles ayant simulé ces scénarios, selon Dentener et al. [7] (notons que l'intervalle sélectionné est plus large que la déviation standard reportée pour le changement d'ozone induit par le scénario 2030 A2 par rapport au scénario présent). Cet intervalle pour l'incertitude du changement d'ozone est appliqué à la différence d'ozone calculée pour chaque jour et dans chaque maille à partir des moyennes glissantes sur $8 \mathrm{~h}$. L'incertitude sur le seuil considéré pour les faibles concentrations correspond aux seuils de 0 et 50 ppb dans la Fig. 3 .

require many simulations. Fig. 4 suggests that the total uncertainty is substantial.

\section{Conclusions}

As indicated by these three scenarios, the future of ozone air pollution and its implications for human health in 2030 can vary considerably. We find that in 2030 under the A2 and CLE scenarios, ozone increases in each of 10 world regions, relative to 2000, with substantial increases in mainly the tropical regions. Ozone decreases in all world regions under the MFR scenario.

These ozone changes cause substantial changes in cases of premature human mortality. In 2030, we estimate a reduction in annual mortalities of about 190,000 due to the emission reductions in the CLE scenario relative to A2, with the greatest reductions in Africa due to the high baseline mortality rates. The MFR scenario causes reductions of about 460,000 mortalities relative to A2, and about 270,000 relative to CLE; avoided mortalities are estimated to be greatest in South Asia due to the substantial growth in ozone in South Asia in A2 and CLE, and substantial decrease in MFR. These benefits of avoided mortalities could be combined with other benefits of reduced ozone for human morbidity, agricultural productivity, and ecosystems, and compared against the estimated costs of achieving the emission reductions under these scenarios [27]. Future work should evaluate changes in surface concentrations of PM under these scenarios, and estimate the avoided cases of PM mortality.

These estimates have large uncertainties, and depend significantly on several parameters. We show that the results decrease strongly for low-concentration thresholds greater than $25 \mathrm{ppbv}$ (for the daily maximum 8-h concentration). Substantial uncertainty also lies in the relationships between emissions and ozone concentrations, as well as the ozone-mortality relationship from epidemiologic studies. Our estimated mortalities would have been roughly $35 \%$ higher had we used the results of recent meta-analyses $[3,12,15]$. Future research is needed to improve scientific understanding and ability to model ozone on a global scale, with greater attention to urban scale processes important for population exposure. Future research should also aim to improve understanding of the mechanisms by which ozone affects human health, and to better quantify its effects on diverse populations globally. 


\section{References}

[1] H.R. Anderson, R.W. Atkinson, J.L. Peacock, L. Marston, K. Konstantinou, Meta-analysis of time-series studies and panel studies of particulate matter $(\mathrm{PM})$ and ozone $\left(\mathrm{O}_{3}\right)$, World Health Organization, Copenhagen, Denmark, 2004.

[2] M.L. Bell, A. McDermott, S.L. Zeger, J.M. Samet, F. Dominici, Ozone and short-term mortality in 95 US urban communities, 1987-2000, JAMA 292 (2004) 2372-2378.

[3] M.L. Bell, F. Dominici, J.M. Samet, A meta-analysis of timeseries studies of ozone and mortality with comparison to the National Morbidity, Mortality, and Air Pollution Study, Epidemiology 16 (2005) 436-445.

[4] M.L. Bell, R.D. Peng, F. Domenici, The exposure-response curve for ozone and risk of mortality and the adequacy of current ozone regulations, Environ. Health Perspect. 114 (2006) 532-536.

[5] V.H. Borja-Aburto, M. Castillejos, D.R. Gold, S. Bierzwinski, D. Loomis, Mortality and ambient fine particles in southwest Mexico City, 1993-1995, Environ. Health Perspect. 106 (1998) 849-855.

[6] F. Dentener, D. Stevenson, J. Cofala, R. Mechler, M. Amann, P. Bergamaschi, F. Raes, R. Derwent, The impact of air pollutant and methane emission controls on tropospheric ozone and radiative forcing: CTM calculations for the period 19902030, Atmos. Chem. Phys. 5 (2005) 1731-1755.

[7] F. Dentener, D. Stevenson, K. Ellingsen, T. van Noije, M. Schultz, M. Amann, C. Atherton, N. Bell, D. Bergmann, I. Bey, L. Bouwman, T. Butler, J. Cofala, B. Collins, J. Drevet, R. Doherty, B. Eickhout, H. Eskes, A. Fiore, M. Gauss, D. Hauglustaine, L. Horowitz, I.S.A. Isaksen, B. Josse, M. Lawrence, M. Krol, J.F. Lamarque, V. Montanaro, J.F. Muller, V.H. Peuch, G. Pitari, J. Pyle, S. Rast, J. Rodriguez, M. Sanderson, N.H. Savage, D. Shindell, S. Strahan, S. Szopa, K. Sudo, R. van Dingenen, O. Wild, G. Zeng, The global atmospheric environment for the next generation, Environ. Sci. Technol. 40 (2006) 3586-3594.

[8] G.A. Folberth, D.A. Hauglustaine, J. Lathière, F. Brocheton, Interactive chemistry in the 'Laboratoire de météorologie dynamique' general circulation model: model description and impact analysis of biogenic hydrocarbons on tropospheric chemistry, Atmos. Chem. Phys. 6 (2006) 2273-2319.

[9] A. Gryparis, B. Forsberg, K. Katsouyanni, A. Analitis, G. Touloumi, J. Schwartz, E. Samoli, S. Medina, H.R. Anderson, E.M. Niciu, H.-E. Wichmann, B. Kriz, M. Kosnik, J. Skorkovsky, J.M. Vonk, Z. Dortbudak, Acute effects of ozone on mortality from the 'Air Pollution and Health: a European Approach' Project, Am. J. Respir. Crit. Care Med. 170 (2004) 1080-1087.

[10] D.A. Hauglustaine, F. Hourdin, L. Jourdain, M.-A. Filiberti, S. Walters, J.-F. Lamarque, E.A. Holland, Interactive chemistry in the 'Laboratoire de météorologie dynamique' general circulation model: description and background tropospheric chemistry evaluation, J. Geophys. Res. 109 (2004) D04314.

[11] D.A. Hauglustaine, J. Lathière, S. Szopa, G.A. Folberth, Future tropospheric ozone simulated with a climate-chemistry-biosphere model, Geophys. Res. Lett. 32 (2005) L24807.

[12] K. Ito, S.F. De Leon, M. Lippman, Associations between ozone and daily mortality: analysis and meta-analysis, Epidemiology 16 (2005) 446-457.

[13] S.Y. Kim, J.T. Lee, Y.C. Hong, K.J. Ahn, H. Kim, Determining the threshold effect of ozone on daily mortality: an analysis of ozone and mortality in Seoul, Korea, 1995-1999, Environ. Res. 94 (2004) 113-119.

[14] J.I. Levy, T.J. Carrothers, J.T. Tuomisto, J.K. Hammitt, J.S. Evans, Assessing the public health benefits of reduced ozone concentrations, Environ. Health Perspect. 109 (2001) $1215-1226$.

[15] J.I. Levy, S.M. Chemerynski, J.A. Sarnat, Ozone exposure and mortality: an empiric Bayes metaregression analysis, Epidemiology 16 (2005) 458-468.

[16] V. Naik, D. Mauzerall, L. Horowitz, M.D. Schwarzkopf, V. Ramaswamy, M. Oppneheimer, Net radiative forcing due to changes in regional emissions of tropospheric ozone precursors, J. Geophys. Res. 110 (2005) D24306.

[17] N. Nakicenovic, R. Swart (Eds.), Special Report on Emissions Scenarios, Cambridge University Press, Cambridge, UK, 2000.

[18] Oak Ridge National Laboratory, Land Scan 2003, http://www. ornl.gov/sci/landscan/index.html, accessed January 2005.

[19] M.S. O’Neill, D. Loomis, V.H. Borja-Aburto, Ozone, area social conditions, and mortality in Mexico City, Environ. Res. 94 (2004) 234-242.

[20] C.A. Pope, R.T. Burnett, M.J. Thun, E.E. Calle, D. Krewski, K. Ito, G.D. Thurston, Lung cancer, cardiopulmonary mortality, and long-term exposure to fine particulate air pollution, JAMA 287 (2002) 1132-1141.

[21] M. Prather, M. Gauss, T. Berntsen, I. Isaksen, J. Sundet, I. Bey, G. Brasseur, F. Dentener, R. Derwent, D. Stevenson, L. Grenfell, D. Hauglustaine, L. Horowitz, D. Jacob, L. Mickley, M. Lawrence, R. von Kuhlmann, J.F. Muller, G. Pitari, H. Rogers, M. Johnson, J. Pyle, K. Law, M. van Weele, O. Wild, Fresh air in the 21st century? Geophys. Res. Lett. 30 (2003) 1100.

[22] J. Schwartz, How sensitive is the association between ozone and daily deaths to control for temperature? Am. J. Respir. Crit. Care Med. 171 (2005) 627-631.

[23] D.S. Stevenson, F.J. Dentener, M.G. Schultz, K. Ellingsen, T.P.C. van Noije, O. Wild, G. Zeng, M. Amann, C.S. Atherton, N. Bell, D.J. Bergmann, I. Bey, T. Butler, J. Cofala, W.J. Collins, R.G. Derwent, R.M. Doherty, J. Drevet, H.J. Eskes, A.M. Fiore, M. Gauss, D.A. Hauglustaine, L.W. Horowitz, I.S.A. Isaksen, M.C. Krol, J.-F. Lamarque, V. Montanaro, J.-F. Muller, G. Pitari, M.J. Prather, J.A. Pyle, S. Rast, J.M. Rodriguez, M.S. Sanderson, N.H. Savage, D.T. Shindell, S.E. Strahan, K. Sudo, S. Szopa, Multimodel ensemble simulations of present-day and near-future tropospheric ozone, J. Geophys. Res. 111 (2006) D08301.

[24] S. Szopa, D.A. Hauglustaine, R. Vautard, L. Menut, Future global tropospheric ozone changes and impact on European air quality, Geophys. Res. Lett. 33 (2006) L14805.

[25] S. Szopa, D. Hauglustaine, Relative impacts of worldwide tropospheric ozone changes and regional emission modifications on European surface ozone levels, C. R. Geoscience (2007) (submitted).

[26] G.D. Thurston, K. Ito, Epidemiological studies of acute ozone exposures and mortality, J. Expo. Anal. Environ. Epidemiol. 11 (2001) 286-294.

[27] J.J. West, A.M. Fiore, L.W. Horowitz, D.L. Mauzerall, Global health benefits of mitigating ozone pollution with methane emission controls, Proc. Natl Acad. Sci. USA 103 (2006) 3988-3993.

[28] World Health Organization, The World Health Report 2004: Changing History, World Health Organization, Geneva, Switzerland, 2004. 